\title{
PENGARUH PENDAPATAN PERKAPITA DAN TINGKAT SUKU BUNGA TERHADAP PERMINTAAN POLIS ASURANSI JIWA
}

\author{
Oleh: \\ Fitroh Yuni Prakatiwi \\ Fakultas Ekonomi Universitas Muhammadiyah Malang
}

\begin{abstract}
The research aimed to (1) find out how much the influence of per capita income and interest level to life-insurance policy demand of AJB Bumiputera 1912 Dieng Branch of Malang, (2) find out variables with dominant influence to the request of life-insurance for AJB Bumiputer 1912 Dieng Branch of Malang, (3) as landscape or information for similar research related with life-insurance in the near future. Data taken by the writer was secondary data where the data found from AJB Bumiputera 1912 Dieng Branch of Malang and BPS Malang. While data used for multiple analysis and hypothesis test using $\mathrm{T}$ test and $\mathrm{F}$ test. Regression analysis result showed that interest level (x1) influenced 4.022152 while per capita income (x2) influenced 11.11860 and determination coefficient 0.930052 . So the strongest variable to the life-insurance request was per capita income (x2) with hypothesis test count 11.11860 where the coefficient determination was 0.930052 .
\end{abstract}

Key Words : interest level, capita income, and life-insurance

\begin{abstract}
ABSTRAKSI
Tujuan dan kegunaan penelitian yaitu (1) untuk mengetahui seberapa besar pengaruh pendapatan perkapita dan tingkat suku bunga terhadap permintaan polis asuransi jiwa AJB Bumiputera 1912 Cabang Dieng Malang, (2) untuk mengetahui variabel-variabel manakah yang mempunyai tingkat pengaruh yang dominant terhadap permintaan asuransi jiwa pada AJB Bumiputera 1912 Cabang Dieng Malang, (3) sebagai landasan ataupun bahan invormasi untuk penelitian serupa yang berhubungan dengan permasalahan asuransi, (4) dapat dipergunakan sebagai sumbangan dalam menentukan kebijaksanaan yang berhubungan dengan pertumbuhan asuransi jiwa dimasa yang akan datang. Data yang diambil oleh penulis adalah data sekunder, dimana data tersebut di peroleh dari AJB Bumioutera 1912 Cabang Dieng Malang dan BPS Cabang Malang. Sedangkan data yang dipergunakan adalah analisa berganda, dan uji hipotesa yang di gunakan oleh uji $\mathrm{T}$ dan uji $\mathrm{F}$. Hasil analisa regresi adalah sebagai berikut tingkat suku bunga (x1) berpengaruh 4.022152 sedangkan pendapatan perkapita (x2) berpengaruh 11.11860 dan untuk koefisien determinasi sebesar 0.930052. Jadi variabel yang paling kuat pengaruhnya terhadap permintaan asuransi jiwa adalah pendapatan perkapita (x2) dengan uji hipotesa hitung sebesar 11.11860 dimana koefisien determinasinya adalah 0.930052 .
\end{abstract}

Kata Kunci : tingkat suku bunga, pendapatan perkapita dan polis asuransi jiwa 
PENDAHULUAN

Manusia dalam kenyataan hidup tak lepas dari berbagai resiko kehidupan yang dapat menimbulkan kehilangan, kerugian ataupun berkurangnya nilai harta benda atau kepentingannya. Kapan hal tersebut terjadi tak seorangpun mengetahui sebelumnya. Untuk itu diperlukan upaya berjaga-jaga untuk penggantian agar standar hidup dan kegiatan tak terganggu atau hilang sama sekali. Resiko yang dihadapi bisa berupa kecelakaan, kematian atau rusaknya benda yang dimiliki. Dalam negara yang sudah maju pola berpikar dan perilaku masyarakatnya akan semakin mantap dan bertanggung jawab, rasa ketergantungan kepada masyarakat lainnya tidak didasarkan atas merugikan atau membebani sesama anggota masyarakat tetapi selalu didasarkan rasa saling membantu yang menguntungkan. Sistem modern yang mampu menanggulangi ketergantungan satu sama lain adalah asuransi jiwa, dimana sistem ini mampu pula memberikan dukungan finansial bagi anggotanya yang mengalami kerugian.

\section{Retnaningtyas}

(2002)

menyatakan Industri asuransi selama ini yang dikenal sebagai lembaga pemberi bantuan kepada pihak yang mengalami kerugian atau penjamin resiko. Resiko yang bisa diperalihkan kepada pihak lain secara ekonomis artinya apabila seseorang karena suatu hal menderita kerugian maka tidak saja demikian ia jatuh, tetapi dengan adanya bantuan pihak asuransi yang bersedia mengambil resiko. Untuk mengambil alih resiko dari masyarakat perusahaan asuransi memungut suatu pembayaran yang disebut premi asuransi. Selain berfungsi sebagai penjamin resiko, industri asuransi juga mempunyai fungsi pokok sebagai penghimpun dana. Menurut Undang-Undang No.2 Th 1992 tentang usaha perasuransian asuransi adalah perjanjian antara dua pihak atau lebih, dengan mana pihak penanggung mengikatkan diri kepada tertanggung, dengan menerima premi asuransi, untuk memberikan penggantian kepada tertanggung karena kerugian, kerusakan atau kehilangan keuntungan yang diharapkan atau tanggung jawab hukum pihak ke tiga yang mungkin 
akan diderita tertanggung, yang timbul dari suatu peristiwa yang tidak pasti, atau memberikan suatu pembayaran yang didasarkan atas meninggal atau hidupnya seseorang yang dipertanggungkan.

Purba (1992) mengatakan Badan yang menyalurkan risiko disebut "tertanggung", dan badan yang menerima resiko disebut "penanggung". Perjanjian antara kedua badan ini disebut kebijakan: ini adalah sebuah kontrak legal yang menjelaskan setiap istilah dan kondisi yang dilindungi. Biaya yang dibayar oleh "tetanggung" kepada "penanggung" untuk risiko yang ditanggung disebut "premi". Ini biasanya ditentukan oleh "penanggung" untuk dana yang bisa diklaim di masa depan, biaya administratif, dan keuntungan.

Berdasarkan undang-undang No 19 tahun 1960 ternyata bahwa sumbangan lembaga asuransi terhadap pembangunan ekonomi adalah:

1. Sebagai alat pembentukan modal

2. Sebagai lembaga saving

Resiko yang mungkin timbul pada asuransi jiwa terutama terletak pada unsur waktu (time), oleh karena sulit untuk mengetahui kapan seseorang meninggal dunia. Hal ini sudah barang tentu akan membawa banyak aspek apabila resiko yang terdapat pada diri seseorang tidak diasuransikan kepada perusahaan asuransi jiwa. Salim (1989) Peranan serta tujuan dari asuransi jiwa adalah sebagai berikut:

1. Dari segi masyarakat umumnya (sosial)

Asuransi jiwa bisa memberikan keuntungan-keuntungan tertentu terhadap individu atau masyarakat, yaitu:

a. Menentramkan kepala keluarga (suami/bapak), dalam arti memberikan jaminan penghasilan, pendididikan, apabila kepala keluarga tersebut meninggal dunia.

b. Dengan membeli polis asuransi jiwa dapat digunakan sebagai alat untuk menabung (saving).

c. Sebagai sumber penghasilan (earning power)

Ini dapat kita lihat pada negara-negara yang sudah maju, seseorang yang merupakan kunci dalam 
perusahaan akan diasuransikan oleh perusahaan di mana ia bekerja. Hal ini perlu dilaksanakan mengingat pentingnya posisi yang dipegangnya. Banyak sedikitnya akan mempengaruhi terhadap kehidupan perusahaan yang "going concern" (sedang berjalan). Misalnya seorang ahli atom/nuclear akan dipertanggungkan jiwanya, bilamana ia meninggal dunia atau sakit, perusahaan wajib membayar ganti kerugian.

d. Sebagai penjamin pengobatan dan menjamin keturunan andai kata yang mengansuransikan tidak mampu mendidik anakanaknya (beasiswa)

2. Dari segi pemerintah/publik

Pembagian kegiatan antara perusahaan negara dari sektorsektor diantaranya:

a. Sektor Produksi (Perusahaan industri negara, Perusahaan perkebunan negara)

b. Sektor Pemasaran (Perusahaan niaga)

c. Sektor Pemberian fasilitas (Perusahaan asuransi negara,
Bank Pemerintah, Dan Perusahaan pelayanan milik negara lainnya)

Jadi bisa digaris bawahi bahwa asuransi jiwa bertujuan untuk menanggung resiko terhadap kerugian finansial tak terduga sebagai akibat karena meninggal dunia terlalu cepat atau hidup terlalu lama.

Dewan asuransi Indonesia (2000) mengatakan Penduduk Indonesia yang lebih dari 200 juta jiwa merupakan pasar yang sangat potensial bagi kalangan industri asuransi jiwa. Dalam "Pasar" diartikan sebagai wilayah distribusi dan sumber tersedianya penutupan asuransi itu sendiri, akan tetapi permintaan terhadap asuransi jiwa masih sangat rendah hal ini terbukti hanya $10 \%$ pendududuk Indonesia yang berinvestasi pada asuransi. Hal ini menunjukan masih belum membudayanya asuransi bagi kalangan masyarakat di Indonesia dan sebagian masyarakat Indonesia masih belum menyadari adanya nilai ekonomis dari dirinya serta kurang percayanya masyrakat terhadap produk asuransi jiwa, padahal 
berdasarkan kajian yuridis mengenai keabsahan berinvestasi pada asuransi jiwa. Berdasarkan Prinsip dasar atau hakekat asuransi di Indonesia dalam pasal 246 Kitab Undang-Undang Hukum Dagang (KURD) dan pasal 1 angka 1 Undang-Undang No. 2 tahun 1992 tentang usaha peransuransian adalah suatu perjanjian yang mengakibatkan peralihan risiko dari tertanggung kepada penanggung.

Wildan (2005) Secara eksplisit, definisi-definisi dari ketentuanketentuan tersebut menyiratkan bahwa pada hakekatnya suatu produk asuransi adalah sebuah perjanjian pengalihan risiko dari tertanggung kepada penanggung. Dalam produk asuransi jiwa unit linked sesuai dengan prinsip asuransi artinya risiko tertanggung telah dialihkan kepada pihak penanggung, kecuali risiko investasinya. Dari pembahasan disimpulkan bahwa Produk asuransi jiwa unit linked adalah produk asuransi jiwa yang mempunyai landasan hukum dan secara sah dipasarkan oleh perusahaan asuransi jiwa di Indonesia. Karena kontribusi didalam kerangka perekonomiain masih terbatas, maka peranan yang di berikan dari perusahaan asuransi belum sekuat jika dibandingkan dengan posisi dan peranan lembagalembaga keuangan lainnya, misalnya lembaga perbankan. Purba (1992) Tujuan masyarakat untuk menjadi anggota asuransi dikarenakan oleh faktor:

\section{Faktor Ekonomi}

Dari segi ekonomi asuransi jiwa dianggap penting bagi masyarakat kerena hakekatnya asuransi jiwa merupakan bentuk kerja sama antara orang-orang yang ingin menghindarkan diri atau minimal untuk mengurangi resiko yang diakibatkan oleh adanya:

a. resiko kematian yaitu suatu peristiwa yang pasti terjadi, tetapi tidak dapat diketahui kapan terjadinya. Kematian mengakibatkan penghasilan hilang dan mengakibatkan kesulitan ekonomi bagi keluarga atau tanggungan yang ditinggalkan.

b. Resiko hari tua yaitu suatu resiko yang pasti terjadi dan dapat diperkirakan kapan hal itu terjadi. Hari tua menyebabkan 
Pengaruh Pendapatan Perkapita dan Tingkat Suku.......(Fitroh Yuni) Prakatiwi

$\begin{array}{lll}\text { kekurang mampuan untuk } & \text { di bawah naungan departemen } \\ \text { memperoleh penghasilan dan } & \text { keuangan. }\end{array}$
mengakibatkan kesulitan ekonomi bagi dari sendiri dan keluarga.

c. Resiko kecelakaan suatu peristiwa yang tidak pasti terjadi, tetapi tidak mustahil terjadi. Kecelakaan kesukaran ekonomi bagi diri sendiri dan keluarga yang menjadi tanggungan.

2. Aspek Finansial

$$
\text { Perusahaan asuransi }
$$
menghimpun dana dari para tertanggung dalam bentuk premi. Dana yang telah terkumpul tersebut, sebagian untuk dana klaim, dan sebagian dana lainnya diinvestasikan dalam bentuk deposito dalam surat-surat berharga (saham obligasi) dalam aktiva tetap seperti kantor dan rumah untuk disewakan sehingga memperoleh penghasilan. Jadi perusahaan asuransi merupakan lembaga keuangan seperti halnya bank di samping sebagai penanggung, maka di Indonesia perusahaan asuransi ditempatkan

\section{METOLOGI PENELITIAN}

Penelitian ini adalah pada perusahaan Asuransi Jiwa Bersama bumiputera 1912 Cabang Dieng Malang.

Jenis peneletian sekunder yaitu suatu metode penelitian dimana sistem pengambilan datanya sudah di olah dan di publikasikan dalam hal ini oleh kantor AJB Bumiputera Cabang Dieng Malang dan kantor BPS.

Sumber data yang diperoleh dari keseluruhan data sekunder yaitu data yang diperoleh tidak dari sumbernya secara langsung melainkan sudah dikumpulkan oleh pihak lain dan sudah dioalah, misalnya dari BPS Kota Malang dan AJB Bumiputera 1912 Cabang Dieng Malang.

Adapun data yang dibutuhkan berupa permintaan asuransi yang dinyatakan dalam bentuk polis, pendapatan perkapita, dan tingkat suku bunga pada tahun 2003-2007 dengan mengunakan data bulananPada penelitian ini, metode data yang digunakan penulis ini 
adalah deskriptif kuatitatif, yaitu kegiatan mengumpulkan, mengolah, dan menyajikan data dari waktu ke waktu. Teknik analisa yang digunakan adalah regresi berganda untuk mengetahui jasa asuransi jiwa yang terjadi. Menurut Sritua Arief, (1993) Adapun rumus yang digunakan adalah sebagai berikut:

$$
\mathrm{Y}=\mathrm{a}+\mathrm{b}_{1} \mathrm{x}_{1}+\mathrm{b}_{2} \mathrm{x}_{2}+\mathrm{e}
$$

Dimana

$$
\begin{array}{ll}
\mathrm{a} & \text { : Bilangan konstanta } \\
\mathrm{b}_{1}, \mathrm{~b}_{2} & \text { : Koefisien Regresi } \\
\mathrm{y} & : \text { Permintaan asuransi yang di } \\
& \text { nyatakan dalam bentuk polis } \\
\mathrm{x}_{1} \quad \text { : Tingkat suku bunga } & \text { Pendapatan perkapita } \\
\mathrm{x}_{2} \quad \text { Pen } & \text { Nilai Residual }
\end{array}
$$

PEMBAHASAN

\section{Tabel 1. Hasil Regresi}

\begin{tabular}{lcccl} 
Variable & Coefficient & Std. Error & t-Statistic & Prob. \\
\hline \hline $\mathrm{C}$ & -2392.764 & 241.4078 & -9.911709 & 0.0000 \\
$\mathrm{X} 1$ & 10.36557 & 2.577122 & 4.022152 & 0.0002 \\
$\mathrm{X} 2$ & 1.851286 & 0.166504 & 11.11860 & 0.0000 \\
\hline \hline R-squared & 0.932550 & Mean dependent var & 1706.281 \\
Adjusted R-squared & 0.930052 & S.D. dependent var & 961.3521 \\
S.E. of regression & 254.2551 & Akaike info criterion & 13.96575 \\
Sum squared resid & 3490865. & Schwarz criterion & 14.07328 \\
Log likelihood & -395.0238 & F-statistic & 373.2983 \\
Durbin-Watson stat & 0.408526 & Prob(F-statistic) & 0.000000 \\
\hline \hline
\end{tabular}

$\overline{\text { Sumber : Eviews data }}=\overline{\text { diolah }}$

Hasil analisis regresi pada table di atas menunjukkan bahwa besarnya nilai konstanta yang dihasilkan adalah $\quad-2392.764$, koefisien untuk variabel $\mathrm{X}_{1}$ (tingkat suku bunga) sebesar 10.36557, koefisien untuk variabel $\mathrm{X}_{2}$ (pendapatan perkapita) sebesar 1.851286. Dengan demkian dapat diperoleh persamaan regresi :

$$
\begin{aligned}
\mathrm{Y}= & -2392.764+10.36557 \mathrm{X} 1+ \\
& 1.851286 \mathrm{X} 2 \\
& \text { Adapun yang dimaksud dalam }
\end{aligned}
$$
persamaan regresi adalah :

$\mathrm{a}=-2392.764:$ merupakan nilai konstanta a yang menunjukkan bahwa apabila tanpa dipengaruhi variabel $\mathrm{X} 1$ (tingkat suku bunga), variabel X2 (pendapatan perkapita) maka jumlah permintan polis 


\author{
AJB Bumiputera 1912 Cabang \\ Dieng Malang akan negatif \\ sebesar - 2392.764. \\ $\mathrm{b}_{1}=10.36557:$ merupakan \\ nilai koefisien regresi variabel \\ X1 (tingkat suku bunga) yang \\ menunjukkan bahwa apabila \\ tingkat suku bunga naik 1 \\ satuan maka permintaan polis \\ AJB Bumiputera 1912 Cabang \\ Dieng Malang akan mengalami \\ kenaikkan sebesar 10.36557. \\ $\mathrm{b}_{2}=1.851286:$ merupakan nilai \\ koefisien regresi variabel $\mathrm{X} 2$ \\ (pendapatan perkapita) yang \\ menunjukkan bahwa apabila \\ pendapatan perkapita \\ meningkat sebesar 1 satuan \\ maka jumlah permintaan polis \\ AJB Bumiputera 1912 Cabang \\ Dieng Malang akan mengalami \\ kenaikkan sebesar 1.851286.
}

\section{Koefisien Determinasi}

Koefisien ini merupakan nilai yang menunjukkan besarnya pengaruh variabel bebas $(\mathrm{X})$ dengan variabel terikat (Y) yang besarnya berkisar antara 0-1 (0\%-100\%), semakin mendekati satu koefisien ini semakin besar pengaruhnya.
Nilai koefisien determinasi sebagaimana pada table analisis regresi adalah sebesar 0.930052 yang berarti bahwa besarnya pengaruh tingkat suku bunga, pendapatan perkapita terhadap permintaan polis AJB Bumiputera 1912 Cabang Dieng Malang adalah sebesar $93 \%$ sedangkan sisanya adalah pengaruh lain yang tidak dikaji dalam penelitian ini.

\section{Pengujian secara simultan dengan uji F (F-test)}

Pengujian ini dimaksudkan untuk mengetahui pengaruh secara simultan tingkat suku bunga dan pendapatan perkapita terhadap permintaan polis AJB Bumiputera 1912 Cabang Dieng Malang. Pengujian ini dilakukan dengan membandingkan nilai F-hitung dengan F-tabel yang menguji hipotesis (Ho) bahwa koefisien regresi sama dengan nol, yang berarti tingkat suku bunga, pendapatan perkapita terhadap permintaan polis AJB Bumiputera 1912 Cabang Dieng Malang. Ho ditolak dan Ha diterima yang berarti secara bersama-sama atau simultan variabel tingkat suku bunga dan pendapatan perkapita 
berpengaruh nyata terhadap dengan demikian nilai F-hitung $>$ Fpermintaan polis jika nilai F-hitung tabel yang berarti bahwa tingkat suku $>$ F-tabel.

Hasil pengujian secara bunga dan pendapatan perkapita secara bersama-sama atau simultan simultan sebagaimana pada tabel analisis regresi menunjukkan bahwa besarnya nilai F-hitung 373.2983 dengan tingkat signifikan $5 \%(0.05)$ diperoleh F-tabel sebesar 4,76 berpengaruh nyata terhadap permintaan polis AJB Bumiputera 1912 Cabang Dieng Malang. Gambar dari hasil pengujian tersebut adalah sebagai berikut :

\section{Gambar 1. Uji Simultan}

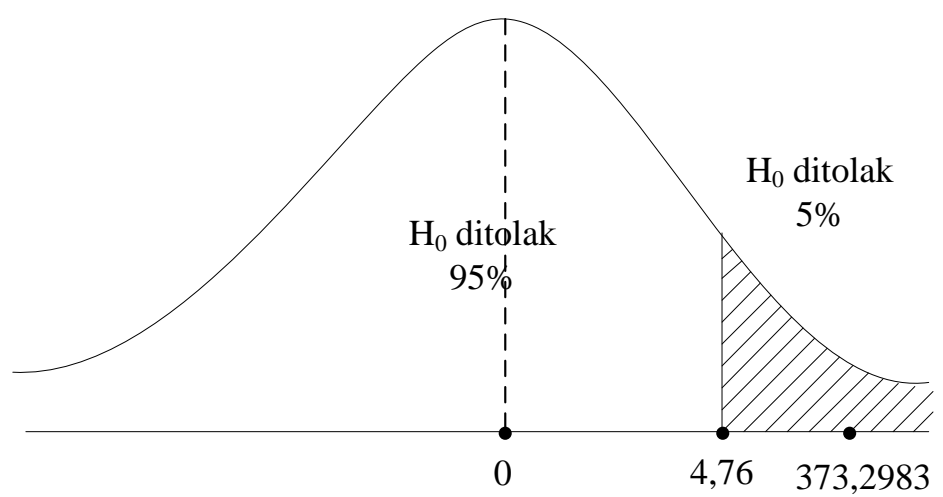

Sumber : Data diolah

Pengujian secara parsial dengan uji t (t- test)

Pengujian ini dimaksudkan untuk mengetahui pengaruh masingmasing variabel terhadap permintaan polis AJB Bumiputera 1912 Cabang Dieng Malang. Pengujian ini dilakukan dengan uji t yaitu dengan membandingkan nilai t-hitung masing-masing variabel dengan nilai t-tabel yang menguji hipotesis nol (Ho). Dari hasil secara parsial sebagaimana pada tabel analisis regresi menunjukkan bahwa variabel $\mathrm{X} 1$ (tingkat suku bunga) nilai $\mathrm{t}$ hitung sebesar 4.022152 dengan tingkat signifikan $5 \%$ diperoleh nilai tabel sebesar 2.26 oleh karena nilai thitung> t-tabel maka Ho ditolak dan Ha diterima yang berarti tingkat suku bunga yang diberikan oleh perusahaan secara parsial berpengaruh nyata terhadap banyaknya permintaan polis AJB 
Pengaruh Pendapatan Perkapita dan Tingkat Suku.......(Fitroh Yuni) Prakatiwi

Bumiputera 1912 Cabang Dieng Malang.
Adapun bentuk hasil pengujian ini sebagaimana pada gambar di bawah

\section{Gambar 2. Uji Parsial Suku Bunga dan Permintaan Polis}

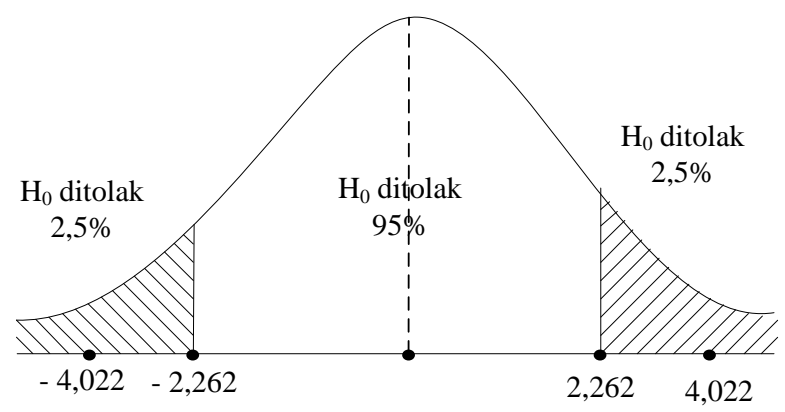

Sumber : Data diolah

Untuk variabel $\mathrm{X} 2$ berpengaruh nyata terhadap (pendapatan perkapita) nilai t-hitung banyaknya permintaan polis AJB sebesar 11.11860 dengan tingkat Bumiputera 1912 Cabang Dieng signifikan $5 \%$ diperoleh diperoleh Malang. nilai tabel sebesar 2.26 oleh karena Adapun bentuk hasil nilai t-hitung $>$ t-tabel maka Ho pengujian ini sebagaimana pada ditolak dan Ha diterima yang berarti gambar di bawah ini :

pendapatan perkapita secara parsial

\section{Gambar 3. Uji Parsial Pendapatan Per Kapita dan Permintaan Polis}

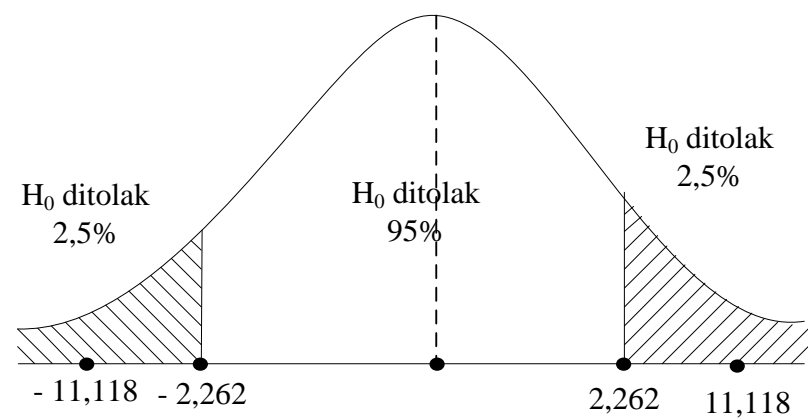

Sumber : Data diolah

Dari hasil analisis data yang dilakukan menunjukkan bahwa variabel X1 (tingkat suku bunga) X2 (pendapatan perkapita) secara 
keseluruhan berpengaruh terhadap permintaan polis AJB Bumiputera 1912 Cabang Dieng Malang.

Untuk menjelaskan variabelvariabel akan dijelaskan sebagai berikut :

\section{Tingkat Suku Bunga}

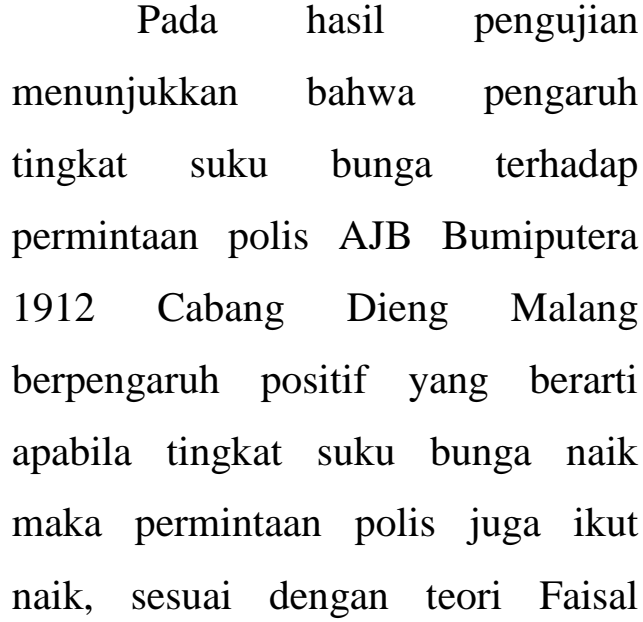
(1996) Besarnya tingkat bunga baik berupa pinjaman atau bunga simpanan akan mempengaruhi terhadap keputusan yang akan diambil oleh nasabah untuk meminjam atau memyimpan uangnya pada lembaga keuangan. Semakin besar bunga simpanan yang diberikan akan menarik minat masyarakat untuk menabungkan uangnya.

\section{Pendapatan Perkapita}

Variabel pendapatan perkapita sangat besar pengaruhnya terhadap permintaan polis AJB Bumiputera
1912 Cabang Dieng Malang hal ini ditunjukkan dengan nialai t-hitung sebesar 11.11860 yang hasilnya menerima hipotesis alternative dan menolak hipotesis nol, berarti kemampuan variabel pendapatan perkapita secara parsial mempengaruhi permintaan polis AJB Bumiputera Cabang Dieng Malang.

Pendapatan perkapita yang meningkat yang di ikuti bertambahnya hasrat masyarakat menjadi nasabah asuransi akan meningkatkan permintaan menjadi nasabah asuransi jiwa di Cabang Dieng Malang karena bertambahnya daya beli masyarakat. Hal ini sesuai dengan teori Sudarman (1989) yang menyatakan ada 4 faktor yang mempengaruhi permintaan individu terhadap komoditi tertentu yaitu harga barang itu sendiri, penghasilan konsumen (demand), selera (taste) dan harga barang lain

a. Uji asumsi klasik

Asumsi-asumsi klasik ini harus dilakukan pengujiannya untuk memenuhi penggunaan regresi linier berganda. Setelah diadakan perhitungan regresi berganda, diadakan pengujian 
uji asumsi klasik regresi. Hasil pengujian di sajikan sebagai berikut :

1. Uji Normalitas

a. Hipotesis:

Ho : $e i \neq 0$, berdistribusi normal

\section{Gambar 4. Jarque Bera}

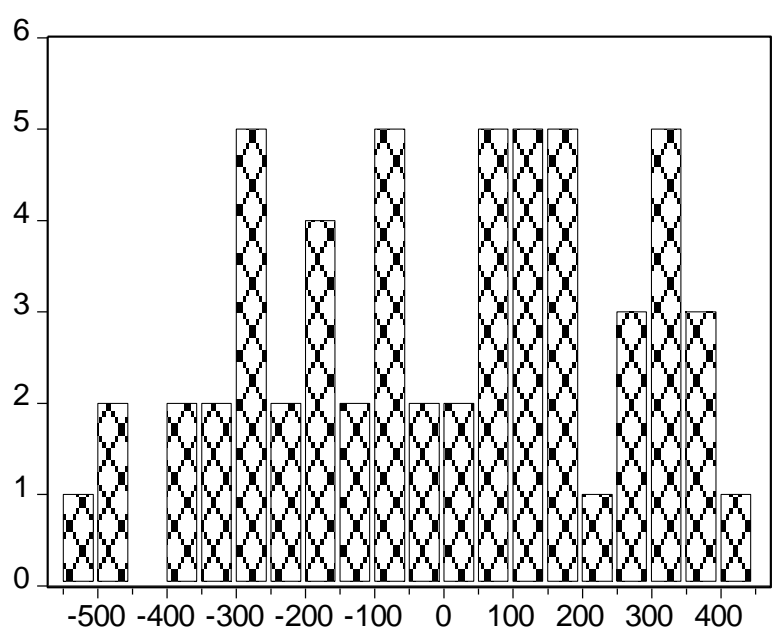

Sumber : Data Diolah

Ketentuan:

Jika Jarque Bera lebih besar dari $\mathrm{X}_{\text {tabel }}^{2}$ berarti Ho ditolak

Jika Jarque Bera lebih kecil dari $\mathrm{X}_{\text {tabel }}^{2}$ berarti Ho diterima

Kesimpulan:

Dari hasil uji normalitas ditemukan bahwa nilai Jarque Bera adalah 2.5305 dan $X^{2}$ tabel 67,5048 dengan $\alpha=5 \% \mathrm{df}=54$, maka Jarque Bera lebih kecil dari $\mathrm{X}^{2}$ tabel berarti menerima $\mathrm{H}_{\mathrm{o}}$ artinya bahwa model yang digunakan memiliki residual
Ha : ei $=0$, tidak berdistribusi normal

b. Menghitung $X^{2}$ tabel Jika $\alpha=5 \%$ df $=54$, maka $X_{\text {tabel }}^{2}=67,5048$

c. Jarque Bera 
Pengaruh Pendapatan Perkapita dan Tingkat Suku.......(Fitroh Yuni) Prakatiwi

adalah apabila nilai $\mathrm{X}^{2}$ hitung uji LM

$>$ dibandingkan dengan nilai $\mathrm{X}^{2}$ tabel

dengan df 2 dan dengan $\alpha=5 \%$.

Maka hipotesis yang menyatakan

bahwa model empirik bebas dari masalah autokorelasi ditolak, dan sebaliknya. Oleh karena $0.096634<$ 5.9915, maka dapat disimpulkan bahwa model empirik hasil estimasi lolos dari masalah autokorelasi.

Tabel 1. Uji ARCH Test.

ARCH Test:

\begin{tabular}{llll}
\hline \hline F-statistic & 0.096634 & Probability & 0.908051 \\
Obs*R-squared & 0.203661 & Probability & 0.903183 \\
\hline \hline
\end{tabular}

Test Equation:

Dependent Variable: STD_RESID ${ }^{\wedge} 2$

Method: Least Squares

Date: 03/15/09 Time: 22:17

Sample(adjusted): 2003:06 2007:12

Included observations: 55 after adjusting endpoints

\begin{tabular}{lrrrl}
\hline \hline Variable & Coefficient & Std. Error & t-Statistic & Prob. \\
\hline \hline C & 1.043199 & 0.257438 & 4.052232 & 0.0002 \\
STD_RESID $^{\wedge}(-1)$ & -0.031181 & 0.139518 & -0.223487 & 0.8240 \\
STD_RESID^2(-2) $^{\wedge} 0.051750$ & 0.139323 & 0.371442 & 0.7118 \\
\hline \hline R-squared & 0.003703 & Mean dependent var & 1.065300 \\
Adjusted R-squared & -0.034616 & S.D. dependent var & 1.086045 \\
S.E. of regression & 1.104682 & Akaike info criterion & 3.089993 \\
Sum squared resid & 63.45676 & Schwarz criterion & 3.199484 \\
Log likelihood & -81.97482 & & F-statistic & 0.096634 \\
Durbin-Watson stat & 1.975188 & Prob(F-statistic) & 0.908051 \\
\hline \hline
\end{tabular}

Sumber : Data Diolah

\section{Uji Multikolinieritas}

Uji multikolinieritas ini dilakukan untuk mengetahui bahwa tidak terjadi hubungan yang sangat kuat atau tidak terjadi hubungan linier yang sempurna atau dapat pula dikatakan bahwa antar variabel bebas tidak saling berkaitan. 
Pengaruh Pendapatan Perkapita dan Tingkat Suku.......(Fitroh Yuni) Prakatiwi

Tabel 2. Hasil estimasi Regress $1\left(\boldsymbol{R}^{2}{ }_{21}\right)$

Dependent Variable: Y

Method: Least Squares

Date: 03/15/09 Time: 01:05

Sample: 2003:04 2007:12

Included observations: 57

\begin{tabular}{lcccc}
\hline \hline Variable & Coefficient & Std. Error & t-Statistic & Prob. \\
\hline \hline $\mathrm{C}$ & -2392.764 & 241.4078 & -9.911709 & 0.0000 \\
$\mathrm{X} 1$ & 10.36557 & 2.577122 & 4.022152 & 0.0002 \\
$\mathrm{X} 2$ & 1.851286 & 0.166504 & 11.11860 & 0.0000 \\
\hline \hline R-squared & 0.932550 & & Mean dependent var & 1706.281 \\
Adjusted R-squared & 0.930052 & & S.D. dependent var & 961.3521 \\
S.E. of regression & 254.2551 & Akaike info criterion & 13.96575 \\
Sum squared resid & 3490865. & Schwarz criterion & 14.07328 \\
Log likelihood & -395.0238 & F-statistic & 373.2983 \\
Durbin-Watson stat & 0.408526 & Prob(F-statistic) & 0.000000 \\
\hline \hline
\end{tabular}

Sumber; Data diolah

Hasil estimasi Regress $2\left(\boldsymbol{R}^{2}{ }_{21}\right)$

Dependent Variable: X1

Method: Least Squares

Date: 03/15/09 Time: 22:04

Sample: 2003:04 2007:12

Included observations: 57

\begin{tabular}{lcccl}
\hline \hline Variable & Coefficient & Std. Error & t-Statistic & Prob. \\
\hline \hline $\mathrm{C}$ & -62.86244 & 9.364368 & -6.712941 & 0.0000 \\
$\mathrm{X} 2$ & 0.054505 & 0.004678 & 11.65177 & 0.0000 \\
\hline \hline R-squared & 0.711685 & Mean dependent var & 44.30000 \\
Adjusted R-squared & 0.706443 & S.D. dependent var & 24.55315 \\
S.E. of regression & 13.30312 & Akaike info criterion & 8.048331 \\
Sum squared resid & 9733.508 & Schwarz criterion & 8.120017 \\
Log likelihood & -227.3774 & F-statistic & 135.7637 \\
Durbin-Watson stat & 0.881111 & Prob(F-statistic) & 0.000000 \\
\hline \hline Sumber ; Data diolah & $=$
\end{tabular}

Berdasarkan hasil regresi, tinggi dibandingkan $\mathrm{R}_{21}^{2}$ dinyatakan ditemukan besarnya nilai $\mathrm{R}_{1}^{2}=$ terbebas dari multikolinier.

0.932550, sementara nilai $\mathrm{R}_{21}^{2}=\quad$ Uji Heteroskedastisitas

0.711685. Dengan demikian, Hasil regresi menunjukkan mengikuti pedoman apabila $\mathrm{R}^{2}$ lebih $\quad$ bahwa f-stat sebesar 3.039086 sedangkan f-tabel sebesar 1.823 (df1 
$=2, \mathrm{df} 2=54, \alpha=5 \%),(\mathrm{f}-\mathrm{stat}<\mathrm{f}-$ tabel). Maka Ho diterima dan Ha ditolak. Berarti pengaruh signifikan dan tidak terjadi Heteroskedastisitas.

\section{KESIMPULAN}

Berdasarkan hasil pengujian baik dengan uji $\mathrm{F}$ (simultan) maupun dengan uji t (parsial) terlihat bahwa tingkat suku bunga dan pendapatan perkapita berpengaruh terhadap permintaan polis asuransi jiwa pada AJB Bumiputera 1912 Cabang Dieng Malang yang ditunjukkan dengan nilai hitung lebih besar dari nilai tabel.

Besarnya pengaruh tingkat
suku bunga dan pendapatan perkapita terhadap permintaan polis asuransi jiwa pada AJB Bumiputera 1912 Cabang Dieng Malang adalah sebesar $93 \%$ yang ditunjukan oleh koefisien determinasi (R2) sebesar 0.93 sedangkan sisanya $0.7 \%$ adalah pengaruh lain yang tidak dikaji dalam penelitian ini.

Diantara variabel $\mathrm{x} 1$ (tingkat suku bunga) dan variabel $\mathrm{x} 2$ (pendapatan perkapita), variabeb x2 (pendapatan perkapita) yang mempunyai pengaruh yang sangat signifikan, hal ini ditunjukkan oleh besarnya t hitung sebesar 11.11860 .

\section{DAFTAR PUSTAKA}

Ali, Hasymi A. Drs, 1993. Bidang Usaha Asuransi. Jakarta : Bumi Aksara.

Arif, Sritua. 1993. Metodologi Penelitian Ekonomi. Jakarta : UI Press

Buku panduan penjualan asuransi jiwa bumi putera.2008.

Gujarati, Damodar. 2002. Ekonometrika Dasar. Jakarta: Erlangga.

Modigliani,dkk. 1999. Pasar \& Lembaga Keungan. Jakarta : Salemba Empat. Nopirin. Ph.d. 1992. Ekonomi Moneter. Yogyakarta : BPFE.

Partadiredja, Ace. 1982. Pengantar Ekonomika. Edisi ke tiga, BPFE, UGM.

Purba, Radiiks. 1992. Memahami Asuransi di Indonesia. Jakarta : PT. Karya Unipress.

Salim, Abbas A. Drs,1991. Dasardasar Asuransi. Jakarta : Rajawali pers. 
Pengaruh Pendapatan Perkapita dan Tingkat Suku.......(Fitroh Yuni) Prakatiwi

Sudarman, Ari. 1989. Teori Ekonomi Mikro. Yogyakarta : BPFE

Sukirno, Sadono. 1985. Ekonomi Pembangunan. Jakarta : Bima Grafika

Wijaya, Faried. DR. M. M.A. 1991. Perkreditan \& Bank Dan Lembaga-Lembaga

Keungan Kita.

Yogyakarta : BPFE.

Winardi. 1979. Pengantar Ilmu

Ekonomi. Bandung http://www.asuransi.mobil.com/asura

nsi-pengertian.htm"

http://www.djlk.depkeu.go.id/asuran

si/hal_3.htm

http://id.wikipedia.org/wiki/Premi

http://www.digilib.ui.ac.id/opac/the

mes/libri2/detail.jsp?id=9

$\underline{5789 \& \text { lokasi }=\text { lokal }}$

www.asuransi_mobile.com.2003

www.bumiputera.com 